\title{
The Adoption of the E-Banking: Validation of the Technology Acceptance Model
}

\author{
Regaieg Essafi Raida, Bouslama Néji \\ Institute of Management Sciences, Tunisia Faculty of Economic Sciences and Management, Tunis, Tunisia \\ Email: regaieg.raida@laposte.net, neji.bouslama@yahoo.fr
}

Received May 27, 2013; revised June 27, 2013; accepted July 4, 2013

Copyright (c) 2013 Regaieg Essafi Raida, Bouslama Néji. This is an open access article distributed under the Creative Commons Attribution License, which permits unrestricted use, distribution, and reproduction in any medium, provided the original work is properly cited.

\begin{abstract}
This paper is based on the technology acceptance model which has been adopted by several previous researches. The purpose of the study is to determine the factors that explain the adoption of e-banking by professional in "Business to Business" relationships. It explores the determinants of use of the Internet in the relationship between bank and firm and it validates the model in Tunisian context. This paper has tested that perceived usefulness and perceived ease determine the attitude of the use, and that attitude determines the intent to use of e-banking by means of the multiple regressions. The originality of this study is the exploration of the determinants of use of e-banking by professional in order to promote its adoption.
\end{abstract}

Keywords: Bank on Internet; Perceived Usefulness; Perceived Ease; Intent to Use

\section{Introduction}

The Technology Acceptance Model is a model of general acceptance for several types of technology. It explains the adoption of information technologies, the adoption of the microcomputer [1] and the adoption of the Internet [2]. In this research, we will inspire to this model [3], which has benefited from a good validation in several empirical studies [4,5], and it explains the behavior of information technology adoption [6]. Thus the proven relevance of Technology Acceptance Model justifies its application to this research. Indeed, given the number of research that supported the Technology Acceptance Model, this model will provide a reference for the identification of the determinants of Internet use in the relationships between bank and firm. So how is the Technology Acceptance Model able to explain determinants of the use of the Internet by the leaders of companies in Tunisia?

\section{The Technology Acceptance Model (Davis 1989)}

The theory of reasoned action was developed by Ajzen and Fishbein [7]. In their model from the research in social psychology, they define the links between beliefs, attitudes, norms and intention. The behavior of the individual is determined by its intention of adoption or rejec- tion, this intention is influenced by subjective standards of the individual and his attitude toward the behavior. This principle was supported by technology acceptance model [3] which has been adopted by several previous researches. However this is able to be supported by our research to explain determinants of acceptance of Internet technology in the relationship between bank and firm. The Technology Acceptance Model (TAM) is a specific model to explain the acceptance and use of new information technologies in organizations [8]. It was developed by Davis in 1989 to explain the behavior of use of the computer [6]. It is based on the fact that the adoption is based on the influence of the perceived ease and the perceived usefulness of the user [9]. The Technology Acceptance Model can predict the determinants of acceptance of a system and guide the experience with the system [5]. The Technology Acceptance Model may explain the success or failure of the adoption of new technologies. It has been supported by the analysis of the determinants of acceptance of e-mail by administrative staff [10]. In this model, Davis makes the relation between the perceived usefulness, perceived ease of use, attitudes and actual behavior for the use of the computer-based technologies. Indeed, Davis identified a number of fundamental variables suggested by previous studies on the determinants of cognitive and emotional of the computer-based 
technology. The model is based on the assumption that the acceptance of the information system is determined by the intentions of using the system. That the intentions are influenced by the attitude of the individual to the use of the information system and that this attitude is influenced by the perceived usefulness and ease of use. It is a model that explains how the characteristics of technology affect perception and later its use [11]. This model has been tested empirically by several studies [11-13]. Technology Acceptance Model was cited 425 times in research between 1989 and 2000 [11]. It has been tested on different groups and organizations and was analyzed by various statistical tools [14]. This model was applied to several modes of uses of technologies such as the use of the e-mail $[3,15]$, the use of the Word processors [15,16], the use of groupware [5], and the use of the world wide web [17].

The original TAM was supported by several researchers such as in presentation of the factors of acceptance of the web site [18], in implementation of the ERP system [19], in the study of the determinants of acceptance of telemedicine [20]. This model was also supported in the context of the use of computers at work [21] and the use of the web [22,23] to test the e-learning. Referring to a Meta-analysis realized between 1980 and 2001 [24], on the work using TAM, all research shows the existence of significant relations between the perceived usefulness, perceived usability, the attitude and intention. Based on the acceptance of the technology model developed by Davis and the attitudinal model [25-27], we will consider that the usefulness and ease of use are therefore the key variables in the model of Davis given the importance of their impact on behavior. Therefore, we consider that the intention of Internet use is influenced by the attitude to the use of the Internet which is determined by the perception of the ease and the usefulness of Internet use.

\section{Conceptual Framework}

\subsection{The Perception of the Use of Internet}

According to De Vito [28] the perception is the process of awareness of many stimuli affecting our senses; it affects the stimuli or messages received. In marketing, "is the process by which a consumer becomes aware of its marketing environment and the interpreter in such a way as it is in agreement with its reference scheme [29]”. The theory of the adoption and diffusion of innovation postulate that use of innovation tend to influence the behavior of the adoption of this innovation [30].

\subsubsection{Ease Perceived of Internet Use}

It's a concept used by the work of the acceptance of the technology. Ease of use means non-complexity and the use of a system without mental effort [3].

It includes the judgments of the efforts required to use technology [3] and expresses the degree to which innovation is difficult to understand or use [30,31]. The perceived usability refers to the effort expected by the individual. This built also refers to the complexity of Rogers [30] which expresses the degree to which the innovation is difficult to understand or use. In 1989, Davis defined the ease perceived by the degree to which the user of the system does not require a great effort. He believes that the facility is: "the degree with which a person grows that the use of a specific system is free of any effort”. Indeed, the user can be to focus on his work and therefore improves its performance. The definitions of the ease of use and the personal efficiency are identical [11,32]. This definition is a criterion to be considered in the design of a tool of ease of use. The concept of usability is widely used in the literature on the acceptance of a technology by users and on the behavior of users. This concept determines the adoption [33]. The ease of use is regarded as an important determinant of the use of the technology [34]. It determines the intent of its use [11]. Katz showed that the complexity of technology and discomfort with the use of the computer, represent obstacles to the adoption of the Internet [35]. Indeed, ease of use affects the intent for the use of the Web [36]. Similarly, in a study conducted in Singapore on a comparison between the adopters of the e-banking and non-adopters of this new financial distribution channel, Gerrard and Cunningham noted that among the factors that influence the adoption of the Bank on the Internet is the fact that they found that the use of Internet offers less complexity [37]. This was also approved by Qureshi and khagan [38]. Thus, at the level of this research and based on the work of Davis [3], ease of use of Internet bank will be seen as a determinant of Internet use.

\subsubsection{Perceived Usefulness of Internet Use}

The perceived usefulness of use is a determinant of satisfaction related to the use of self-service technologies [39]. It is considered as being the perception of the positive consequences of the use; it refers to the perceived benefit [40]. This is the concept of comparative advantage developed in the theory of the adoption [41], which is considered to be the degree to which innovation is seen as offering a greater benefit [42]. The concept of usefulness of information technology is derived from the work of Davis on the acceptance of information technology. This author defined usefulness by the additional contribution that can improve the performance and efficiency of the work. It suggests that if users see that they have an advantage by the use of a technology, then the likelihood of its use increases [3]. Where he believes that the usefulness of use refers to the degree with which the use of 
the technology improves the performance of the user in the organization [30], and assimilate the concept of usefulness to benefit, "defined as the degree to which an innovation is seen as being better than its formulated precursors". The perceived utility refers to the benefits that the organization think derive from the use of the Internet in terms of gain of time, gain money, convenience and access to additional information [6,30]. It equates utility and functionality [43]. Perceived usefulness is one of the determinants of use. It is an important determinant of the intent of the use of the technology [44] as the use of the Internet [45] and the acceptance of the use of the online bank [38]. Bendana and Rowe show that the utility of use influences consumption on the Internet and based on the fact that the benefit of innovation is positively correlated with the rate of adoption [46]. We will consider in this research that usefulness perceived of the use is one of the factors supporting the use of Internet.

\subsection{Attitude of the Use of Internet}

The concept of attitude occupies a central place in the analysis of the behavior of the consumer. Traditionally, attitudes are considered sustainable mental predisposations, speaking in a manner favorable or unfavorable to the object and that lead the individual to respond in a determined sense. The attitude is the psychological tendency depending on a degree of favor or disfavor [47]. It may refer to one of the perceived benefits [40]. The attitude expressed positive or negative evaluation to make the behavior [3]. A first difficulty related to this concept is the abundance and variety of the definitions. Other authors have defined the attitude, by establishing a relationship between attitude and needs with which it is associated. Howard offers the following definition: "the attitude to a mark is defined as the degree of satisfaction of its requirements that the consumer considers that this brand can bring him.” [48]. The attitude towards innovation explains the adoption decision and it is considered as an explanatory determinant of the acceptance of the use of technology $[3,30]$. Indeed, the attitude towards the merchant site is represented as the predisposition of Internet users to respond in a manner favorable or unfavorable to a web site [49].

\subsection{The Intent of the Use of Internet}

Ajzen and Fishbein define the intent as an intermediate factor between attitude and behavior. They demonstrated the existence of a relationship between the behavior and intent [7]. The theory of reasoned action and the theory planned behavior are theories explaining the intention. One of the key to the success of implementation of new technologies is the intention of their use [50]. The use of a system is a reflection of the acceptance of the technol- ogy by users [11]. The use of new technologies [24], or even their current adoptions are determined by the behavioral intention of their uses [42].

\section{Perception and Attitude}

The perception of the characteristics of the use of the Internet is the first factor that determines the formation of attitudes towards this new technology. In effect, the approach adopted for Internet is the result of processing the user of certain attributes and characteristics of the Internet tool [51].

- The ease of the perceived use and attitude to the use of the Internet: We consider that the adoption or not of trade depends on the attitude which is a function of the perceived ease of use of the Internet [26-52]. Perceived ease of use positively affects the attitude to the use of self-service technology and specifically the use of the Internet [52]. Indeed, very often the difficulties of navigation are cited as barriers to purchase online [53]. The ease of use influences consumption on the Internet $[3,46]$. The diffusion of innovations depends on the perception of the complexity of the product, so we can consider that the perception of the degree of difficulty of use of the Internet is one of the explanatory factors of its use which affects the degree of its dissemination [30-54].

The perceived usability is a determinant of the attitude towards the interactive shopping [55]. The ease of use and perceived usefulness are the determinants of attitudes toward the use of online stores [49], also Bangaly Kaba in an application to the case of Quebec concerning the study of the adoption of cell phones said the existence of a positive influence of the ease of use on attitudes. Thus, the difficulty of use can create a negative attitude towards the use of Internet. Indeed, many consumers use the new techniques of self service that traditional techniques of the fact that they perceived ease of use [39-56]. According to the theory of reasoned action, Ajzen and Fishbein require the existence of a causal relationship between the ease of use and the attitude to the use of technology. According to data collected from one hundred and four Canadian organizations, the usefulness of perceived use affects the purchase on the Internet [46]. The perceived difficulty therefore has a direct impact on the attitude to the use of the Internet [5]. Indeed, more the users will think that buying on the Internet is difficult, more their attitude to the use will be negative [8]. In the context of the adoption of Internet, Dulyalak, Settapong and Lederer supports the existence of a positive relationship between the ease of use and intend to use [6-17]. The ease of use of the Internet allows the adoption of the financial services in banking [57]. Some others authors found that the ease of use of the Internet affects the attitude to its use [27-58]. So we will consider that users who see ease of use to the 
Bank on the Internet will have a favorable attitude towards its use.

H1: The ease perceived the use of Internet in the relationship between banks and firm positively influences the attitude of its use.

- The usefulness of the perceived use and attitude to the use of the Internet.

Perceived use consequences influence behavior by an indirect effect via attitudes. Indeed, in information system [59], there is a causal relationship between the perceived usefulness of the use and the attitude to the use of the technology [1]. Nelson, Todd and Davis report that the acceptance of a system and therefore its use is due for much utility $[3,15]$. Other studies have also reported that the utility is positively related to the use of a system [60]. The usefulness of e-mail is considered a dimension that has a direct effect on the satisfaction of users and on the degree of use of the tool. On the use of the Internet, the perceived use of usefulness is source of a positive attitude $[27,39,60]$. The perceived utility is the first determinant of the use of online stores [41]. In the banking, perceived usefulness of Internet is a determinant of the attitude to its use [61]. So we will consider that the adoption depends on the attitude which is a function of the value perceived in the use of the Internet. Where we will lead to the following hypothesis:

H2: The value perceived in Internet use in the relationship between bank and firm positively influences the attitude of its use.

\section{Attitude and Intent to Use}

Several studies require the existence of a positive relationship between a positive attitude and intent of acquisition [62]. Thus psychologists developed the hypothesis that attitudes influence the behavior [63]. The attitude is a factor that influences the behavior [64]. It's directly correlated with intention [25]. So there is a large and significant link between attitude and intention of adoption [1]. According to Al Ali, the characteristics of innovation beliefs determine the intention of the behavior [65]. Thus, the attitude is considered as a determinant for the use of the technologies $[3,24,26]$. A favorable attitude to the use of the Internet can have a positive effect on the intention to use this new technology of self-service $[25,26]$. In this same context, Internet use is influenced by attitudes to the use of the Internet [66,67].

The behavior on the web is influenced by the attitude of the individual to this new technology [68]. This is also verified at the level of the Bank on the Internet [61]. Based on these theoretical developments, we will consider that:

H3: The attitude to the use of the Internet in the rela- tionship between bank and firm influences positively the intention of use.

\section{Methodology of Research}

The questionnaire was administered at 130 Tunisian business leaders by following the method of convenience. The questionnaire was administrated conducted according to the technique of face to face (118 questionnaires) and the technique of administration via Internet (12 questionnaires). Concerning the operationalization of variables, we are based on the adaptation of the existing measures scales in the literature to the context of Internet use at the relationship between bank and firm. Factor analysis was conducted under SPSS17, accordingly to determine the dimensionality of the scales of measurement. We conduct ACP analysis with varimax rotation. To ensure the purification and the reliability of the scales of measures adapted to the use of the Internet in the relationship between bank and firm, we assessed cronbach alpha (its value varies between 0.778 and 0.96). We have retained the factors having a value greater than 1 (the value varies between 1.812 and 4.324). The items with low factor contributions (less than 0.50 values) and those whose contributions were shared between several factorial axes have been eliminated. To test causal relationships, we will apply the methods of linear regressions.

\subsection{Test of the Influence of Perceived Ease and Perceived Usefulness on the Attitude}

To test the influence of ease and usefulness perceived on the attitude to the use of the Internet, we used the method of multiple regression and we verified the absence of high co linearity between the explanatory variables (perceived usefulness and perceived ease). Tolerances and VIF are close 1 and within the recommended limit (VIF $=1.152$ is less than 3 and tolerance $=0.868$ is greater than 0.3). Explanatory variables usefulness and perceived ease of use are not correlated, which is indicating a quality of the model index. So we can go to test the influence of the perceived usefulness and ease on the attitude to the use. The calculated $\mathrm{F}$ is equal to 79.756 , which is greater than the critical value of $F(2,127)=2.82$ (at the level of confidence 0.05 ), so we can conclude that the regression model is of quality. $\mathrm{R}$ square $=0.557$, it means that the model explains $55.7 \%$ of the variation of the intention of Internet.

- Impact of perceived ease on the attitude:

Ease $\mathrm{T}=4.745$, it's greater than 1.96 , and the sign of Beta is positive (0.301), (Table 1) so we can conclude that ease perceived of Internet has a positive impact on the attitude to its use, so the $\mathrm{H} 1$ hypothesis is validated.

- Impact of the perceived usefulness on attitude:

$\mathrm{T}$ attitude $=9.179$, it's greater than 1.96 and the sign 
Table 1. Influence of the ease and usefulness on the attitude.

\begin{tabular}{ccccc}
\hline $\begin{array}{c}\text { Variable } \\
\text { to explain }\end{array}$ & $\begin{array}{c}\text { Explanatory } \\
\text { variables }\end{array}$ & $\begin{array}{c}\text { Regression } \\
\text { coefficients }\end{array}$ & $\begin{array}{c}\text { Student's } \\
\mathbf{T}\end{array}$ & $\mathbf{p}$ \\
\hline Attitude & $\begin{array}{c}\text { Perceived } \\
\text { ease } \\
\text { Perceived }\end{array}$ & 0.301 & 4.745 & 0.00 \\
& \begin{tabular}{c} 
usefulness \\
\hline
\end{tabular}
\end{tabular}

Note: Prepared from the data collected by the researcher.

of Beta is positive (0.582), (Table 1) therefore we conclude that usefulness perceived the use of Internet has a positive influence on the attitude to its use, so the $\mathrm{H} 2$ hypothesis is validated.

\subsection{Test of the Influence of the Attitude on the Intention}

The calculated $\mathrm{F}$ is equal to 108 . 057 , which is greater than the value critical $(1,128) \mathrm{f}=3.84$ (at the level of confidence 0.05 ), so we can conclude that the regression model is of quality. $\mathrm{R}$ square $=0.458$, which means that attitude explains $45.8 \%$ of the variation of intent.

$\mathrm{T}$ in absolute value is equal to 10.395 , which is greater than 1.96 (significant) and the sign of Beta is positive (0.667) (Table 2). We can conclude that attitude influences positively the intention of Internet use in the relationship between banks and firm therefore the H3 hypothesis is validated. The results converge with the hypotheses assumed by TAM and other previous research which supported it by postulating that the ease of use positively influence the attitude to the use which influences positively to turn the intention of using the Internet in the relationship between bank and firm. Finding that this technology is clear and understandable and easy to operate motivates the behavior of the user who will experience an attitude conducive to the use, as a consequence the triggering of intent to positive use. The usefulness of the use is revealed through the positive contributions of the use such as the improvement of the performance of the work, the development of a positive appreciation of technology deemed as beneficial to the management of the company. This variable will in turn positively influence the attitude which will positively influence the intention of Internet use in the in the relationship between bank and firm (Figure 1).

There is the model tested in the Tunisian context to explain the determinant of the use of Internet banking by the leaders. This model tested in our study demonstrate that perceived ease and perceived usefulness determines the attitude and that attitude determine the intent if use of e-banking.

\section{Conclusion}

The majority of existing research explaining the deter-
Table 2. Influence of the attitude on the intention.

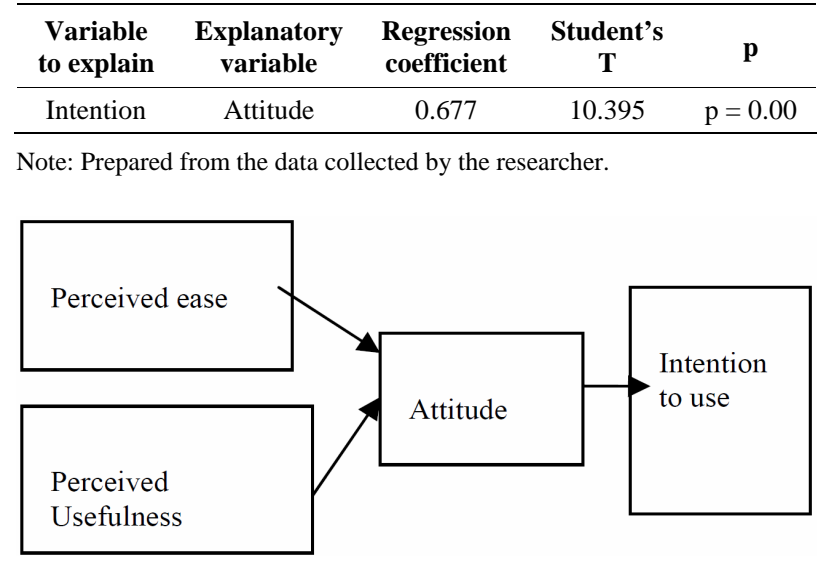

Note: Tested in Tunisian context in order to determine the use of e-banking by the leaders.

Figure 1. The model explained the determinants of the use of Internet banking.

minants of the use of Internet technology is based on the factors of explanation of the adoption at the report the "Business to Consumer". But in the "Business to Business" report, it is important to understand the diffusion of technology among professional. The determination of explanatory factors of the intention of Internet use in the relationship between bank and firm became more necessary competitiveness. Thus, through explaining the factors that determine the intention of Internet used in the relationship between bank and firm, we are referred to the TAM model which has been widely supported by previous research $[3,25,27]$ and we have tested the TAM model in the context of the use of technology among professionals.

\section{REFERENCES}

[1] M. Igabria, G. B. Davis and T. Guimaras, "Testing the Determinants of Microcomputer Usage via Structural Equation,” Journal of Management Information System, Vol. 11, No. 4, 1995, pp. 9-30.

[2] M. C. Cheung and C. Chang, "Perceptual Factors Underlying User Preferences toward Product Form of Mobile Phones," Industrial Ergonomics, Vol. 27, No. 4, 2001, pp. 247-258. doi:10.1016/S0169-8141(00)00054-8

[3] F. D. Davis, R. P. Bagozzi and P. R. Warshaw, "User Acceptance a Computer Technology: A Comparison of Two Theoretical Models,” Management Science, Vol. 35, No. 8, 1989, pp. 982-1003. doi:10.1287/mnsc.35.8.982

[4] K. Mathieson, "Predicting User Intentions Comparing the Technology Acceptance Model with the Theory of Planned Behavior," Information Systems Research, Vol. 2, No. 3, 1991, pp. 173-191. doi:10.1287/isre.2.3.173

[5] S. Taylor and P. A. Todd, "Understanding Information Technology Usage: A Test of Competing Models,” Information System Research, Vol. 6, No. 2, 1995, pp. 144176. 
[6] D. Phuangthon and S. Malisawan, "A Study of Behavioral Intention for 3G Mobile Internet Technology: Preliminary Research on Mobile Learning," A Proceedings of the 2nd International Conference on E-Learning for Knowledge-Based Society, Bankok, 4-7 August 2005.

[7] I. Ajzen and M. Fishbein, "Understanding Attitudes and Predicting Behavior,” Prentice Hall Inc., Upper Saddle River, 1980.

[8] I. Zaoui and A. E. Akremi, “L'intention D'achat du Consommateur sur Internet: Déterminants et Rôle Modérateur de la Confiance, cas du site Marchand du Magasin Général,” The 8th AIM Conférence, Grenoble, May 2003.

[9] D. Harker and Van Akkeren, "Mobile Data Technologies and SME Adoption and Diffusion: An Empirical Study on Barriers and Facilitators," The Australian Journal of Information Systems, Vol. 9, No. 2, 2002, pp. 3-16.

[10] D. François and S. P. Antoin, "Une Analyse des Déterminants de L'acceptation de la Messagerie Electronique par des Personnels Administratifs à L'université," Système d'Information et Management, Vol. 7, No. 4, 2002, p. 127.

[11] V. Venkatesh and F. D. Davis, “A Theoretical Extension of the Technology Acceptance Model: Four Longitudinal Studies,” Management Science, Vol. 46, No. 2, 2000, pp. 186-204. doi:10.1287/mnsc.46.2.186.11926

[12] G. C. Bruner and A. Kumar, "Explaining Consumer Acceptance of Handheld Internet Devices," Journal of Business Research, Vol. 58, No. 5, 2005, pp. 553-280. doi:10.1016/j.jbusres.2003.08.002

[13] Y. Foxalle and Pallister, "Technology Acceptance: A Meta Analysis of the TAM," Journal of Modeling in Management, Vol. 2, No. 3, 2007, pp. 251-280.

[14] D. Gefen, "E-Commerce: The Role of Familiarity and Trust,” Omega, Vol. 28, No. 6, 2000, pp. 725-737. doi:10.1016/S0305-0483(00)00021-9

[15] D. R. Adams, R. N. Peter and A. Tod, "Perceived Usefulness, Ease of Use and Usage of Information Technology: A Replication,” Management Information System Quarterly, Vol. 16, No. 2, 1992, pp. 227-247.

[16] R. P. Bagozzi and R. Warshaw, "User Acceptance of Computer Technology: A Comparison of Two Theoretical Models," Management Science, Vol. 35, No. 8, 1989, pp. 982-1003. doi:10.1287/mnsc.35.8.982

[17] A. L. Ledrer, D. J. Maupin, M. P. Sena and Y. Zhuang, "The Role of Ease of Use, Usefulness and Attitude in the Prediction of World Wide Web Usage,” CRP, 1998.

[18] E. Huang, “The Acceptance of Women-Centric Websites," The Journal of Computer Information Systems, Vol. 45, No. 4, 2005, pp. 75-83.

[19] A. K. Gyampah and F. Salam, “An Extension of Technology Acceptance Model in an ERP Implementation Environment, Information and Management, Vol. 41, No. 6, 2004, pp. 731-745. doi:10.1016/j.im.2003.08.010

[20] P. Y. K. Chau and P. Hu, "Investigating Health Care Professionals Decisions to Accept Telemedicine Technology: An Empirical Test of Competing Theories," Information and Management, Vol. 39, No. 4, 2004, pp. 297-311.

[21] S. S. Liaw and H. M. Huang, “An Investigation of User
Attitudes toward Search Engines as an Information Retrieval Tool," Computers in Human Behavior, Vol. 19, No. 6, 2003, pp. 751-765. doi:10.1016/S0747-5632(03)00009-8

[22] F. Lin and J. Wu, “An Empirical Study of End-User Computing Acceptance Factors in Small and Medium Enterprises in Taiwan: Analyzed by Structural Equation Modeling," Journal of Computer Information Systems, Vol. 44, No. 3, 2004, pp. 98-108.

[23] N. Ndubisi, R. Supinah and P. Gurting, “The Extend Technology Acceptance Model and Internet Banking Usage Intention,” International Logistics Congress Proceeding, Turkey, December 2004.

[24] P. J. Legris and P. C. Ingham, "Why Do People Use Information Technology, A Critical Review of the Technology Acceptance Model," Information and Management, Vol. 40, No. 3, 2003, pp. 191-204.

[25] L. Moez and F. Selma, “Les Déterminants de L'achat sur Internet: Revue de la Littérature et Proposition de Modèle,” 2004. www.iae.univ-nantes.fr/emarket/emarket

[26] J. R. Leroy Robinson, W. Greg Marshall and M. B. Stamps, "Sales Force Use of Technology: Antecedents to Technology Acceptance,” Journal of Business Research, Vol. 58, No. 12, 2005, pp. 1623-1631.

[27] C. E. Porter and N. Donthu, "Using the Technology Acceptance Model to Explain How Attitudes Determine Internet Usage: The Role of Perceived Access Barriers and Demographics," Science Direct, Journal of Business Rerearch, Vol. 59, No. 9, 2006, pp. 999-1007.

[28] J. A. DeVito, "Les Fondements de la Communication Humaine,” Edition Gaétan Morin, 1993.

[29] C. Dussart, "Comportement du Consommateur et Stratégie de Marketing,” McGraw Hill, New York, 1983, p. 77.

[30] M. Rogers, "Diffusion of Innovations," 4th Edition, The Free Press, New York, 1995.

[31] G. C. Moore and I. Benbasat, "Development of an Instrument to Measure the Perceptions of Adopting an Information Technology Innovation," Information Systems Research, Vol. 2, No. 3, 1991, pp. 192-222.

[32] T. Hill, N. D. Smith and M. F. Mann, "Role of Efficacy Expectations in Predicting the Decision to Use Advanced Technologies: The Case of Computers," Journal of Applied Psychology, Vol. 72, No. 2, 1987, pp. 307-313.

[33] E. Karahanna and D. W. Straub, "The Psychological Origins of Perceived Usefulness and Ease of Use,” Information and Management, Vol. 35, No. 4, pp. 237-250.

[34] I. Ajzen, "From Intentions to Actions: A Theory of Planned Behavior, Action Control: From Cognition to Behavior,” New York, 1985.

[35] J. Katz, "Motives, Hurdles and Droputs," Communications of the ACM, Vol. 40, No. 4, 1997, pp. 97-102.

[36] P. Don and R. Martha, "Le One to One: Valoriser Votre Capital Client,” Les Editions d’Organisation, 1998.

[37] P. Gerrad and J. B. Cunningham, "The Diffusion of Internet Banking among Singapore Consumers,” International Journal of Bank Marketing, Vol. 21, No. 1, 2003, pp. 16-28. doi:10.1108/02652320310457776

[38] T. M. Qureshi, M. K. Zafar and M. B. Khan, "Customer 
Acceptance of Online Banking in Developing Economies," Journal of Internet Banking and Commerce, Vol. 13, No. 1, 2008, p. 1. www.arraydev.com/commerce/jibc/

[39] M. L. Matthew, A. L. Ostrom, R. I. Roundtree and M. J. Bitner, "Self-Service Technologies: Understanding Customer Satisfaction with Technology-Based Service Encounters," Journal of Marketing, Vol. 64, No. 3, 2000, pp. 50-64. doi:10.1509/jmkg.64.3.50.18024

[40] A. K. Au and P. Enderwick, "A Cognitive Model on Attitude toward Technology Adoption,” Vol. 15, No. 4, 2000, pp. 266-282.

[41] L. D. Chen, M. L. Gillenson and D. L. Sherrel, "Enticing Online Consumers: An Extended Technology Acceptance Perspective," Information Management, Vol. 39, No. 8, 2002, pp. 705-719. doi:10.1016/S0378-7206(01)00127-6

[42] L. Moez, M. Khalifa and A. Frini "What Makes Consumers Buy from Internet? A Longitudinal Study of Online Shopping," IEEE Transaction on Systems, Man and Cybermetics, Vol. 30, No. 4, 2000, pp. 421-432. doi:10.1109/3468.852436

[43] N. C. Goodwin, "Functionality and Usability," Communication of the ACM, Vol. 30, No. 3, 1987, pp. 229-233.

[44] P. Y. K. Chau, “An Empirical Assessment of a Modified Technology Acceptance Model,” Journal Management Information Systems, Vol. 13, No. 2, 1996, pp. 185-204.

[45] A. L. Ledrer, D. J. Maupin, M. P. Sena and Y. Zhuang, "The Technology Acceptance Model and the World Wide Web,” Decision Support Systems, Vol. 29, No. 3, 2000, pp. 269-282. doi:10.1016/S0167-9236(00)00076-2

[46] M. Bendana and F. Rowe, “Du Minitel à l'Internet: Perception du Risque et Transition Chez les Internautes Utilisateurs des Services Bancaires,” Annales des Télécommunications, Vol. 58, No. 1-2, 2003, pp. 197-211.

[47] A. H. Eagly and S, Chaiken, "The Psychology of the Attitudes," Harcourt Brace College Publishers, New York, 1993.

[48] J. A. Howard, "Consumer Behavior in Marketing Strategy,” Prentice Hall, Englewood Cliffs, 1989.

[49] Q. Chen and W. D. Wells, “Attitude toward the Site,” Journal of Advertising Research, Vol. 39, No. 5, 1999, pp. 27-37.

[50] C. Amel, "Implantation d'un ERP (Entreprise Ressource Planning): Antécédents et Conséquence,” XVème Conférence Internationale de Management Stratégique, Annecy/ Genéve, 13-16 June 2006.

[51] S. Debbabi, S. Baile and M. Daassi, "La Fidélité à un Site Marchand: Les Déterminants et le Rôle Médiateur de la Confiance et de la Satisfaction," Actes du Colloque Cyber-Gestion, Montpellier, 2003.

[52] A. O'cass and T. Frenech, “Web Retailing Adoption: Exploring the Nature of Internet Users Web Retailing Behavior,” Journal of Retailing and Consumer Services, Vol. 10, No. 2, 2003, pp. 81-94. doi:10.1016/S0969-6989(02)00004-8

[53] C. Ranganathan and S. Garrapathy, "Key Dimensions of Business to Consumer Web Sites," Information and Management, Vol. 39, No. 6, 2002, pp. 457-465. doi:10.1016/S0378-7206(01)00112-4
[54] G. Alexander, "La Notion de Confiance et le Droit du Commerce Electronique,” LX Electronica, Vol. 12, No. 3, 2008, pp. 1-20.

[55] T. L. Childers, J. Peck and S. Cason, "Hedonic and Utilitarian Motivations for Online Retail Shopping Behavior," Journal of Retailing, Vol. 77, No. 4, 2001, pp. 511-535. doi:10.1016/S0022-4359(01)00056-2

[56] P. A. Dabholkar, "Consumer Evaluation of New Technology-Based Self Service Options: An Investigation of Alternative Models of Service Quality,” International Journal of Research in Marketing, Vol. 13, No. 1, 1996, pp. 29-51. doi:10.1016/0167-8116(95)00027-5

[57] M. Weiss, "Bricks to Clicks: What Drives Customer Use of the Internet in a Multi-Channel Environment," Working Papers, 2000.

[58] M. S. Sohail and B. Shanmugham "E-Banking and Customer Preferences in Malaysia: An Empirical Investigation,” Information Sciences, Vol. 150, No. 3-4, 2003, pp. 207-217. doi:10.1016/S0020-0255(02)00378-X

[59] N. K. Malhotra and J. D. McCort, “A Cross-Cultural Comparison of Behavioral Intention Models: Theoretical Consideration and an Empirical Investigation,” International Marketing Review, Vol. 18, No. 3, 2001, pp. 235269. doi:10.1108/02651330110396505

[60] R. L. Thompson, C. A. Higgins and J. M. Howell, "Personal Computing: Toward a Conceptual Model of Utilization,” Management Information System, Vol. 15, No. 1, 1991, pp. 125-143. doi:10.2307/249443

[61] J. M. Pearson and Md N. Khalil, "The Influence of Trust on Internet Banking Acceptance," Journal of Internet Banking and Commerce, Vol. 12, No. 2, 2007, 10 p. www.arraydev.com/commerce/jibc/

[62] R. P. Bagozzi, "Attitudes, Intentions and Behavior: A Test of Some Key Hypotheses,” Journal of Personality and Social Psychology, Vol. 41, No. 4, 1981, pp. 607627. doi:10.1037/0022-3514.41.4.607

[63] C. Derbaix and J. Bree, "Comportement du Consommateur, Présentation des Textes Choisis," Edition Economica, Paris, 2000.

[64] J. V. Petrof, “Comportement du Consommateur et Marketing,” Les Presses de l’Université Laval, Quebec City, 1998.

[65] Al A. Samer, "La Crédibilité Perçue Comme Facteur Explicatif du Comportement des Internautes,” Journée du e-Marketing, Université de Nantes, Nantes, 2004.

[66] J. H. Zhu and H. Zhou, "Diffusion, Use and Impact of the Internet in Hong Kong: A Chain Process Model,” Journal of Computer Mediated Communication, Vol. 7, No. 2, 2002. www;Ascusc.org/jcmc/vol7/issue2/hongkong.html

[67] D. J. Atkin, L. W. Jeffres and K. A. Neuendorf, "Understanding Internet Adoption as Telecommunications Behavior," Journal of Broadcasting and Electronic Media, Vol. 42, No. 4, 1998, pp. 475-409. doi:10.1080/08838159809364463

[68] J. Moon and Y. Kim, "Extending the Tam for a Word Wide Web Context," Information and Management, Vol. 38, No. 4, 2001, pp. 217-230. doi:10.1016/S0378-7206(00)00061-6 